\title{
An Analytical Study to Assess the Factors Affecting Abuses among Married Women at Selected Areas of Egypt
}

\author{
Gehad Mohamed Abo El Matty Shahbo ${ }^{1}$, Bindu Bharathi ${ }^{2}$ \\ Ph.D, MSN, BSN, RN, RM ${ }^{1}, M S N, B S N, R N, R M^{2}$ \\ ${ }^{I}$ Assistant Professor, Community Health Nursing, Faculty of Nursing, Port- Said University, Egypt \\ ${ }^{2}$ Lecturer, Faculty of Nursing, Northern Border University, Saudi Arabia
}

\begin{abstract}
Woman abuse is a violation of the rights of women by a socially unacceptable behavior. It has negative impact on the wellbeing of women community. The aim of the study was to analyze the factors affecting women abuse among married women. An objective of the study was to identify the socio-demographic data of the married women, to assess the factors affecting women abuse, and to recognize types of abuses experienced by the women. Analytical survey design was the research methodology. Proportionate Stratified Random Sampling technique was used for collecting data from married Public Health Nurses and Nursing Teachers. Sample size was 170. Settings of the study were Primary Health Centers and School of Nursing, Port-Said City, Egypt. A semi structured interview schedule was the tool for data collection. Result of the study shows that, among 170 samples, $38.8 \%$ of the subjects were between the age group of 41-50 years. About $34.7 \%$ of the aggressor was husband. Around $41 \%$ of the samples were victims of slapping, $29 \%$ of them were experiencing different forms of physical abuse, and $26 \%$ of the subjects were experiencing exposure of violence once in a week. About 54\% of the samples were the victims of personal insult and $14 \%$ of their husband's were having aggressive behavior. Among 170 samples, $14 \%$ of the subjects were getting abuse words from their husbands. Around 54\% of the subjects were getting abuses in front of their children, so the children were the witness of their father's abuse. out of 170 samples, $46.5 \%$ of the sample's husbands were always making quarreling without reason. Women abuse is highly prevalent and dangerous in our population. Nurses play an important role in the restoration of physical and psychological health of these women. Main recommendations of the study was to arrange Women Empowerment Classes for women on self protection, self motivation, and self esteem measures, Promotion and revision of supportive laws for abused women. Arrange counseling sessions for the victims and their families. Finally help the Women to become Self Assertive to overcome the challenges of life.
\end{abstract}

Key words: Women abuse, physical abuse, sexual abuse and different forms of violence

\section{Introduction}

Woman abuse is a violation of the rights of women by a socially unacceptable behavior. It has negative impact on the wellbeing of women community. ${ }^{1}$

Violence and abuse affect women from all kinds of backgrounds every day. Sometimes, women are attacked by strangers, but most often they are hurt by people who are close to them. Violence and abuse can cause terrible physical and emotional pain ${ }^{2}$. Women abuse is a negative attempt to control the behavior of a wife. Women abuse occurs when a husband threatens or harms his spouse to gain power and control over her; this includes emotional, physical and sexual abuse. ${ }^{3}$

Recognizing women abuse in developing countries has emerged as a growing concern among researchers and Policymakers interested in women's health and empowerment ${ }^{4}$. In developing countries, women are vulnerable to many forms of violence.

\section{1. Need and significance of the study}

Estimated one out of every three women worldwide will be physically, sexually or otherwise abused during her lifetime - with rates reaching $70 \%$ in some countries. Violence against women and girls includes harmful practices that range from rape to domestic violence, to acid burnings and dowry deaths, and so-called "honor killings." Violence against women and girls is a human rights violation, a public health epidemic and a barrier to solving global challenges. It devastates the lives of millions of women and girls - in peacetime and in conflict — and knows no national or cultural barriers. Most importantly, it must end. ${ }^{5}$

${ }^{\mathrm{T}}$ he United States of America, between 1-4 million women experiences serious assault by an intimate partner each year; $47 \%$ of the men who beat their wives do so at least 3 times per year ${ }^{6}$. It has been estimated that 1 in every 10 women in Canada is abused by her partner every year ${ }^{7}$. Acts of violence against women cause more death and disability than cancer, malaria, traffic accidents and war combined. Although violence against women is recognized as a major public health problem ${ }^{8}$. 
Now, with the increased awareness of the pervasiveness of this phenomenon and its devastating psychological and physical impact it is important to determine the extent of the problem in the community

Therefore, the researchers, decided to conduct an analytical study to assess the factors affecting abuses among married women of Port-Said City in Arab Republic of Egypt.

I. 2. Statement of the problem

An Analytical study to assess the factors affecting abuses among married women at selected areas of

Egypt

I. 2. Aim of the study

The aim of the study was to analyze the factors affecting abuses among married women.

I. 3. Objectives

1. To assess the socio- demographic data of the married women

2. To analyze the factors affecting women abuse.

3. To recognize the types of abuses experienced by the women

II. 1. Research Approach: Quantitative Approach

II. 2. Research Design: Analytical Survey design was used in this study.

II. 3. Setting of the Study: This study was conducted at selected Primary Health Centers of Port -

Said City, Egypt. Primary Health Centers (PHC) are: Osman Ebn Affan PHC, El Manakh PHC,

Profound PHC, Elkaboty PHC and Nursing School of Port - Said City, Egypt.

II. 4. Sampling Technique: Proportionate Stratified Random Sampling Technique was used in this study

II. 5. Population: Married Women

II. 6. Sample size: 170

II. 7. Sample: The subject of the present study was selected by Proportionate Stratified Random Sampling

Technique i.e. 150 Married Public Health Nurse from Primary Health Centers and 20 Married

Teachers from School of Nursing, Port- Said City, Egypt. They consisted of 170 married women. The age of subjects may range from $20-50$ years.

II. 8. Inclusion Criteria: Public Health Nurses and Nursing Teachers available at the time of data collection. Exclusion Criteria: Not willing to participate in the study.

\section{9. Research Tool}

A semi structured interviewing schedule was the tool. It includes three sessions:

The first session was on socio- demographic data of the subjects. It includes age, marital status, educational level, occupation, religion, husband's job and husband's age. The second session was on types of abuses, exposure of abuses and its consequences. Third session was on abuse assessment screen (developed by Nursing research consortium on violence and abuse ) which include a map allows the specific injuries to be diagrammed and information about the injuries noted .Center for Social Research Abuse Index (CSR Abuse index). Emotional abuse checklist, Checklist for danger assessment. Interview is designed to identify, if the women is living in an abusive situation. Each possible answer has points assigned to it. By answering each question and then totaling these points as directed, CSR Abuse Index (Interpretation of Score Chart: Dangerously abusive (120-140), Seriously abusive (93-37), Moderately abusive(36-15), Non abusive(14-0). So, the researcher can understand whether she is living in a potentially violent situation and can estimate how really dangerous that abuse.

\section{9. Ethical consideration}

Purpose of the study was explained to all the participants of the study. Informed written consent was obtained from all subjects. Confidentiality and privacy was maintained during interview. All the Ethical principles were followed during entire study.

\section{10. Data collection process}

The researcher were attended (Primary Health Centers (PHC) : Osman Ebn Affan PHC, El Manakh PHC, Profound PHC, Elkaboty PHC and and Nursing School of Port - Said City, Egypt) the settings 4 days per week from 9 am to $1 \mathrm{pm}$, Proportionate Stratified Random Sampling Technique was used to collect the data. This technique was selected because Public Health Nurses are more than the Nursing Teachers. So 150 Public Health Nurse were included in this study. It includes strata of Public Health Nurses from different Primary Health Centers (PHC). Osman Ebn Affan PHC (40 Nurses), El Manakh PHC (40 Nurses), Profound PHC (35 Nurses), Elkaboty PHC (35 Nurses) and another strata of Nursing Teachers from Port-Said School of Nursing (20 Teachers), Port-Said City. Semi structured interview schedule was used for data collection. Interview was the techniques followed in this study. The researcher was met individually with 1-3 subjects per day. After explanation of the purpose of the study informed written consent was obtained. Data collection period for this study was 3 months; it was carried out in the period from June 2013 to till the end of August 2013. 


\section{11. Statistical analysis:}

The data was analyzed with the help of SPSS (Statistical Package for Social Science).

III. Figures And Tables

Table 1: Distribution of the subject according to Socio- demographic Variables

$\mathrm{n}=\mathbf{1 7 0}$

\begin{tabular}{|c|c|c|}
\hline Socio- demographic Variables & Frequency & Percentage (\%) \\
\hline Age In Years 20-30 & 18 & $10.6 \%$ \\
$31-40$ & 46 & $27.1 \%$ \\
$41-5$ & 66 & $38.8 \%$ \\
$51-60$ & 40 & $23.5 \%$ \\
\hline Marital status & 157 & $92.4 \%$ \\
Married & 02 & $01.2 \%$ \\
Divorced & 11 & $06.4 \%$ \\
Widow & 167 & $98.2 \%$ \\
Religion & 03 & $01.8 \%$ \\
Muslim & & \\
Christian & 128 & $75.29 \%$ \\
\hline Educational status & 42 & $24.71 \%$ \\
\hline Secondary School & &
\end{tabular}

Table 1 depicts that, among 170 samples, $38.8 \%$ of the subjects were between the age group of 41 50 years. Majorities (92.4\%) of the samples were married and belongs to Muslim religion (98.2\%). Around $75.29 \%$ of the subjects have secondary school education, and $24.71 \%$ have University education.

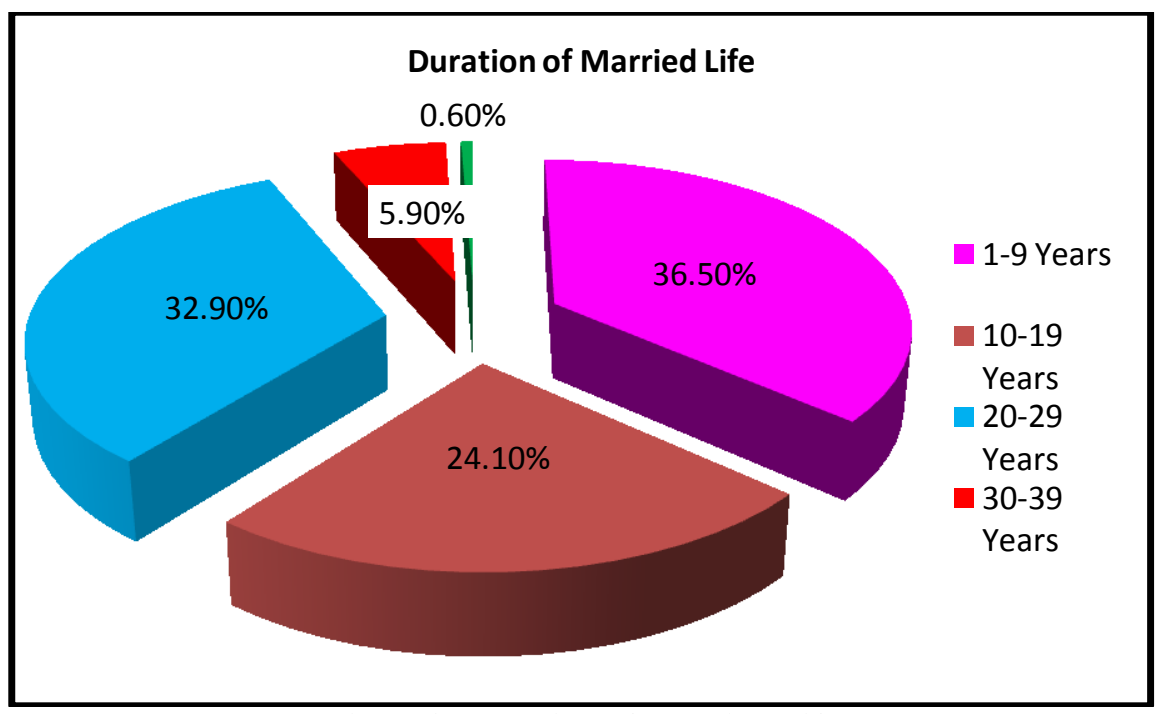

Figure1: Duration of Married Life

Figure 1 depicts the duration of married life, $32 \%$ of the subjects have more than 20 years of married life and $36.5 \%$ of the subjects were having $1-9$ years of married life.

Table 2: Frequency distribution of studied subjects according to their family profile

\begin{tabular}{|c|c|c|}
\multicolumn{2}{|c|}{$\mathbf{n = 1 7 0}$} \\
\hline Variable & Frequency & Percentage (\%) \\
\hline Number of Children- Daughter & & \\
Nil & 45 & $26.5 \%$ \\
$1-3$ & 120 & $70.6 \%$ \\
More than 3 & 05 & $02.9 \%$ \\
\hline Number of Children- Son & 47 & \\
Nil & 120 & $27.6 \%$ \\
$1-3$ & & $70.6 \%$ \\
\hline
\end{tabular}


An Analytical Study to Assess the Factors Affecting Abuses among Married Women

\begin{tabular}{|c|c|c|}
\hline More than 3 & 03 & $01.8 \%$ \\
& & \\
\hline Husband's Educational level & 14 & $8.2 \%$ \\
Preparatory school & 102 & $60.0 \%$ \\
Secondary school & 54 & $31.8 \%$ \\
University & 01 & $0.6 \%$ \\
Husband's job & 06 & $03.5 \%$ \\
Professional & 99 & $58.2 \%$ \\
Worker & 17 & $10.0 \%$ \\
Employee & 47 & $27.7 \%$ \\
Retired & & \\
Private work & & \\
\hline
\end{tabular}

Table 2 shows that, $70 \%$ of the samples have 1-3 numbers of daughter and son and $60 \%$ of the samples husbands were studied up to secondary school, $58.2 \%$ of the husbands are employed.

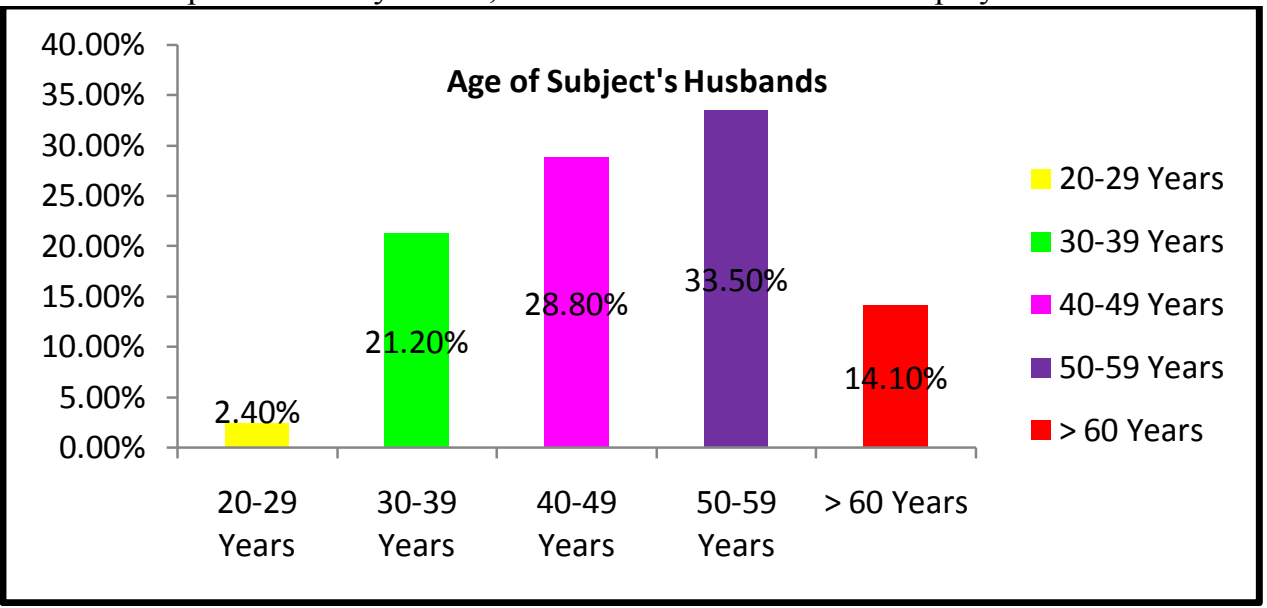

Figure 2: Age of Subject's Husbands

Figure 2 depicts the age of subject's husband, $33.5 \%$ of the samples husband's age was in between 50 -59 years and $21.2 \%$ were between $30-39$ years.

Table (3) Frequency distribution of subjects according to their knowledge on violence, source, and frequency of violence $\mathbf{n}=\mathbf{1 7 0}$

\begin{tabular}{|c|c|c|}
\hline Variable & Frequency & Percent (\%) \\
\hline Knowledge on Violence & 130 & 76.5 \\
Yes & 40 & 23.5 \\
No & & 34.7 \\
The aggressor & 59 & 04.1 \\
Husband & 07 & 61.2 \\
Husband's brother & 104 & \\
No & 17 & $25.75 \%$ \\
Once & 09 & $13.63 \%$ \\
Twice & 04 & $06.06 \%$ \\
Three times & 36 & $54.54 \%$ \\
\hline
\end{tabular}

Table 3 depicts that, $77 \%$ of the samples were aware about violence, $34.7 \%$ of the aggressors were husbands, and $26 \%$ of the subjects were exposed to violence once in a week. 


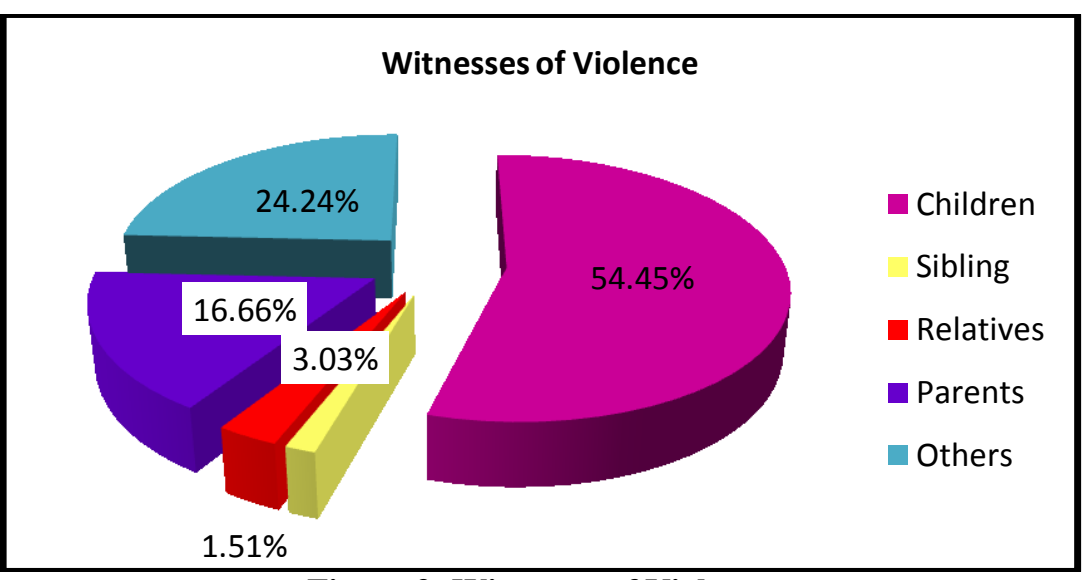

Figure 3: Witnesses of Violence

Figure 3, depicts that $54 \%$ of the witness of violence was their own children, $16.6 \%$ of the witnesses were their parents.

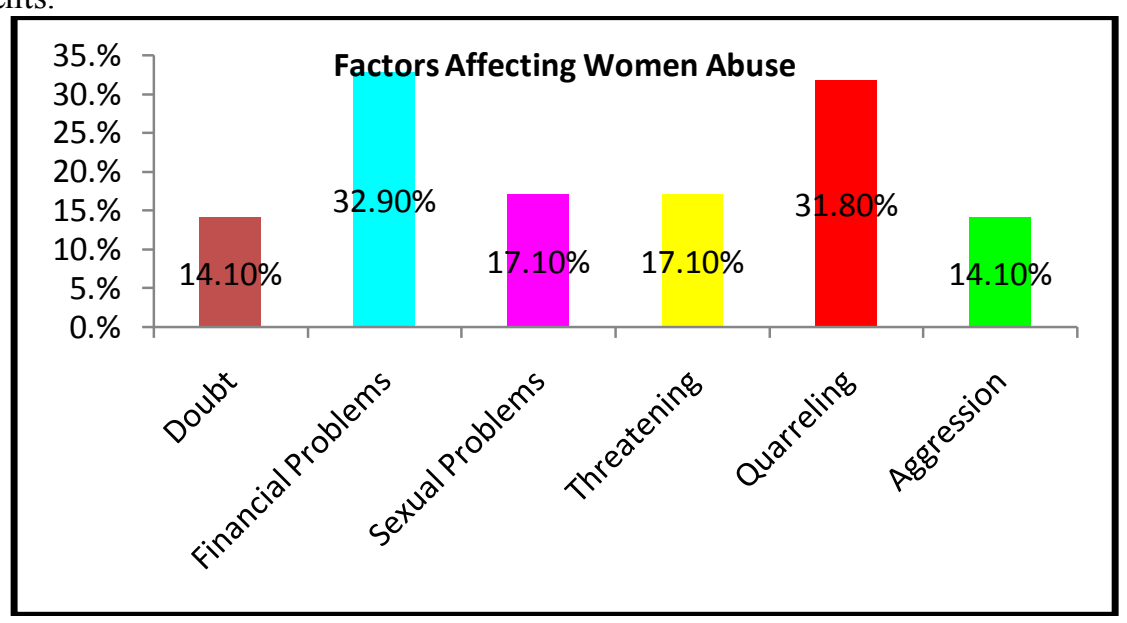

Figure4: Factors Affecting Abuse

Figure 4 , depicts the factors affecting abuses, $33 \%$ of the subjects were getting abuse due to financial problems. $14 \%$ of the samples were suffered from husband's doubt, $17 \%$ of their husband's making problems on sex. $14 \%$ of their husband's were having aggressive behavior. $17 \%$ were fear from threats of their husband. $32 \%$ were experiencing quarreling from their husbands.

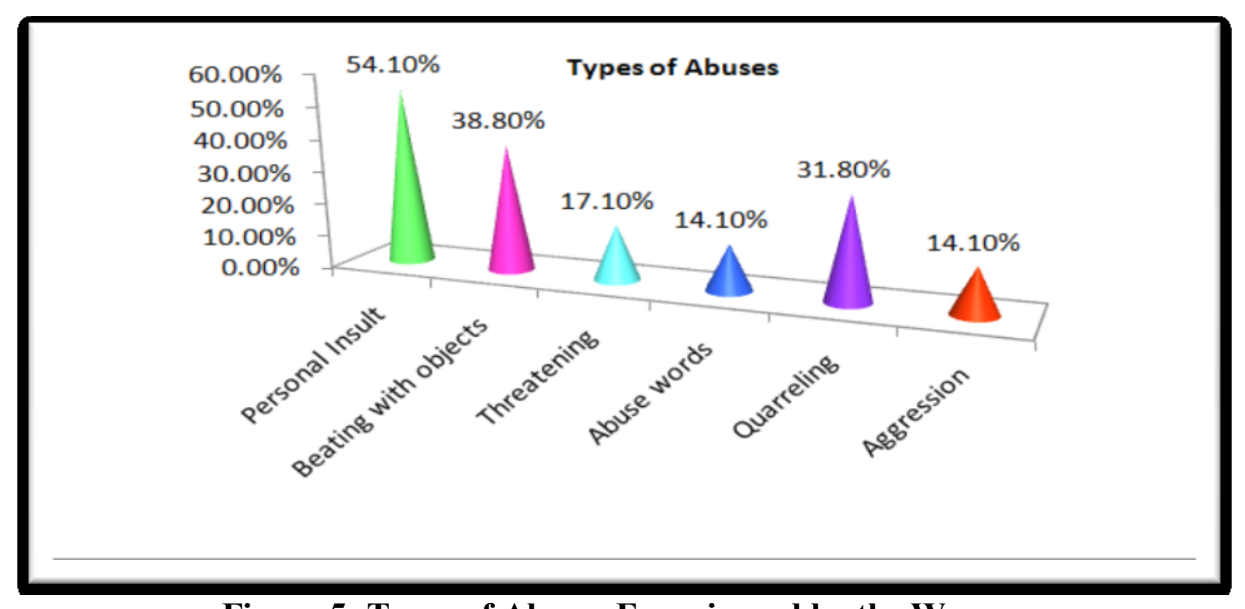

Figure 5: Types of Abuses Experienced by the Women

Figure 5 , depicts that $54 \%$ of the samples were the victims of personal insult, $39 \%$ were getting beating with objects, $14 \%$ of their husband's were having aggressive behavior. $14 \%$ of the subjects were getting abuse words from their husbands. $17 \%$ were fear from threats of their husband. $32 \%$ were experiencing quarreling from their husbands. 


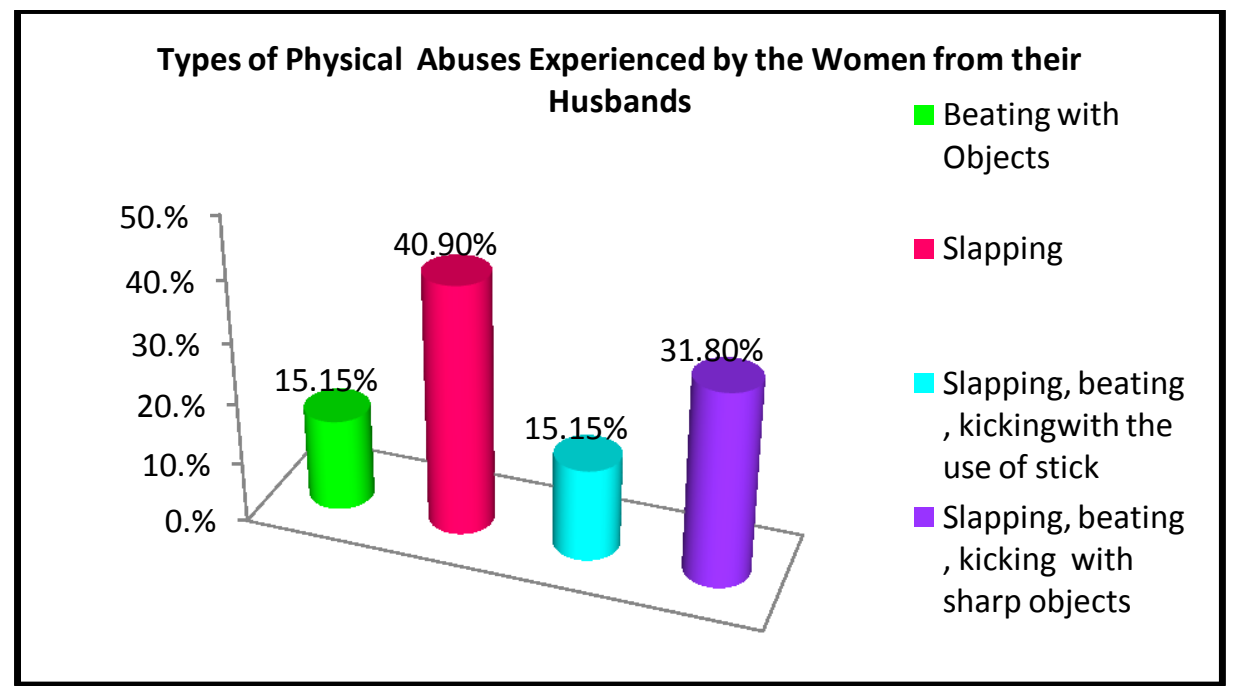

Figure 6: Types of Physical Abuse

Figure: 6 depict that, $41 \%$ of the samples were the victims of slapping, $31.8 \%$ were getting physical abuses with sharp objects and $15.5 \%$ were suffered from beating with objects.

Table 4: Frequency distribution of subjects according to Husband's mood, reason for quarreling, criticizing character, and threat

\begin{tabular}{|c|c|c|}
\hline & \multicolumn{2}{|c|}{$n=170$} \\
\hline Variable & Frequency & Percent (\%) \\
\hline $\begin{array}{l}\text { Husband's Mood } \\
\text { Very calm } \\
\text { Moderate } \\
\text { Aggressive }\end{array}$ & $\begin{array}{c}14 \\
135 \\
21\end{array}$ & $\begin{array}{l}08.2 \\
79.4 \\
12.4\end{array}$ \\
\hline $\begin{array}{l}\text { Reason for Quarrelling } \\
\text { Nothing } \\
\text { Children } \\
\text { Education and child rearing }\end{array}$ & $\begin{array}{l}79 \\
50 \\
41\end{array}$ & $\begin{array}{l}46.5 \\
29.4 \\
24.1\end{array}$ \\
\hline $\begin{array}{l}\text { Criticizing Character } \\
\text { Don't criticize them at all } \\
\text { Criticize them on Cooking } \\
\text { Criticize them on Dressing } \\
\text { Criticize them on Appearance }\end{array}$ & $\begin{array}{l}70 \\
40 \\
24 \\
36\end{array}$ & $\begin{array}{l}41.2 \\
23.5 \\
14.1 \\
21.2\end{array}$ \\
\hline $\begin{array}{l}\text { Threatening Behavior } \\
\text { Don't threaten her at all } \\
\text { Husband's is threatening her with } \\
\text { Verbal words } \\
\text { Suicide or killing her }\end{array}$ & $\begin{array}{l}141 \\
07 \\
22\end{array}$ & $\begin{array}{l}82.9 \\
04.1 \\
12.9\end{array}$ \\
\hline
\end{tabular}

Table 4 depicts that, $12 \%$ of the sample's husbands were having aggressive behavior, $79 \%$ have moderate behavior. About $46.5 \%$ of the samples husbands were always making quarreling without reason, $29 \%$ of them were making quarrelling for their children, $23.5 \%$ of the subjects were getting criticism on cooking, and $21 \%$ on appearance, $14 \%$ for dressing, $13 \%$ of the samples were getting frequent threat on suicide or killing from their husband.

IV. Results of The Study

Among 170 samples, $38.8 \%$ of the subjects were between the age group of $41-50$ years. $92.4 \%$ of the samples were married. Regarding duration of married life, $32 \%$ of the subjects were having more than 20 years of married life. Majority (98.2\%) of the samples were Muslims. About $75.29 \%$ of the subjects were have secondary School education, and $24.71 \%$ have University education.

Seventy percentages of the samples have 1-3 children of both genders. About $33.5 \%$ of the subject's husband's age was in between 51-60 years. More than half (60\%) of the sample's husbands were studied up to secondary school, and $58.2 \%$ of the husbands were employed. 
Among 170 samples, $77 \%$ of the samples were aware about violence, $34.7 \%$ of the aggressor was husbands, $41 \%$ of the samples were victims of slapping, $29 \%$ of them were experiencing different forms of physical abuse, and $26 \%$ of the subjects were experiencing exposure of violence once in a week.

Fifty four percentages of the samples were the victims of personal insult, $39 \%$ of them were getting beating with objects, $32 \%$ were experiencing quarreling with their husbands and $33 \%$ have financial problems. $14 \%$ of the samples were fear from husband's doubt, $17 \%$ of their husband's making problems on sex. About $14 \%$ of their husband's were having aggressive behavior and $14 \%$ of the subjects were getting abuse words from their husbands. Around $17 \%$ of them were feared from threats of their husband. More than half ( $54 \%$ ) of the witness of violence was their own children, $16.6 \%$ of the witnesses were their parents.

Among 170 samples, $12 \%$ of the sample's husbands were having aggressive behavior, $79 \%$ have moderate behavior. Around half (46.5\%) percentage of the samples husbands were always making quarreling without reason, $29 \%$ of their husbands were making quarrelling on children, $23.5 \%$ of the subjects were getting criticism on cooking, and $21 \%$ on appearance, $14 \%$ for dressing, $13 \%$ of the samples were getting frequent threat on suicide or killing from their husband.

According to Centre for Social Research Abuse Index Scale 44.13\%, 22 \%, 35\%, 22.94\% and 10.58\% of our study subjects lives in non abusive, moderately abusive, seriously abusive and dangerously abusive environment respectively.

\section{1. Discussion}

In the present study findings revealed that $54 \%$ of the samples were the victims of personal insult, $39 \%$ were getting beating with objects, 32\% were experiencing quarreling with their husbands and $33 \%$ have financial problems. $14 \%$ of the samples were fear from husband's doubt, $17 \%$ of their husband's making problems on sex. 14\% of their husband's were having aggressive behavior. $14 \%$ of the subjects were getting abuse words from their husbands. $17 \%$ were fear from threats of their husband. $54 \%$ of the witness of violence was their own children, $16.6 \%$ of the witnesses are their parents. Although violence against women is recognized as a major public health problem, few interventions have been developed to reduce abuse ${ }^{1}$. The United States of America, between 1-4 million women experiences serious assault by an intimate partner each year ; $47 \%$ of the men who beat their wives do so at least 3 times per year ${ }^{6}$. It has been estimated that 1 in every 10 women in Canada is abused by her partner every year ${ }^{7}$. Acts of violence against women cause more death and disability than cancer, malaria, traffic accidents and war combined. Although violence against women is recognized as a major public health problem ${ }^{8}$.

Among 170 samples, $38.8 \%$ of the subjects were between the age group of 41-50 years and $92.4 \%$ of the samples were married. Regarding duration of married life, $32 \%$ of the subjects have more than 20 years of married life. $98.2 \%$ of the samples were Muslims. $75.29 \%$ of the subjects have secondary School education, $24.71 \%$ have University education. $70 \%$ of the samples have 1-3 girls and boys. $33.5 \%$ of the subject's husband's age was in between 51-60 years. 60\% of the samples husbands were studied up to secondary school, $58.2 \%$ of the husbands are employed. Regarding socioeconomic characteristic, most subjects were aged between 30 to 50 years and most of them were married for more than 10 to 20 years, which made them more vulnerable to violence. The present study revealed the issue of early marriage. According to anecdotal evidence, customary (Urfi) marriage is increasing in Egypt. Reports also revealed that summer marriage of young Egyptian girls from low income families to wealthy Arab tourists in return for a bride - price, the relations end in divorce. This study finding agrees with other studies. It found that, social and cultural factors were not mentioned as much as potential other factors by married women; for whom substance abuse and men's mental problems ranked high.

Their findings were consistent with another study from the USA, which was a public opinion survey on domestic violence. Couple violence is the most common types of physical aggression in the general population of married spouses and cohabiting partners, and is prepared by both men and women this result agree with other study findings. The majority of the women were subjected to psychological abuse, often in combination with severe physical violence repeatedly over time ${ }^{9}$. This study disagrees with the findings of women's socio-demographic characteristics did not much affect their opinions about causes of Violence among women. However, academic women introduced an ecological approach for the explanation of Violence Among Women (VAW). In order to get a better understanding of the gendered power relations behind Violence Among Women, similar studies with various community members -including men- are needed. Gender discrimination at universities should be further investigated as an important research topic ${ }^{10}$.

Psychological points of view, an evolutionary imbalance of power between men and women resulting in a situation where more than $90 \%$ of the victims of this power abuse were women. ${ }^{11}$ Women abuse occurs as 
physical, sexual, emotional, verbal, economic, intellectual and spiritual abuse. These findings are consistent with present study findings. About $54 \%$ of the samples were the victims of personal insult, $39 \%$ were getting beating with objects, $32 \%$ were experiencing quarreling with their husbands and $33 \%$ have financial problems and non-visible were treated solely for their injuries and pass through the healthcare system unnoticed ${ }^{13}$.

As regard the number of children boys and girls, the study found that most of the sample was to have 3 children, because children also working for the family to maintain financial status. More than half of the sample's children were with his father and they are continuing the job of the father. Then also the income is not sufficient for the family. So the financial problems are existing in the family. This also led to the violence against women and children. Because financial burden is coming to the father's shoulder only, so he is getting frustrations due to financial problems. This result supported by a common finding in many studies is that poor socio-economic conditions contribute to violence in the family ${ }^{14}$.

The National Violence against Women survey, which found that $7.7 \%$ of all U.S. women are raped by an intimate partner and $24.8 \%$ experience partner-perpetrated physical and/or sexual abuse in their lifetime. Likewise, in the present study women's lifetime physical abuse rate $(58 \%)$ is about twice the prevalence (30\%) reported in a statewide telephone survey of 3,130 Georgia women aged 15-44 and nearly double the prevalence (37\%) of lifetime emotional or physical abuses reported in a large study of over 1,600 women aged 18-39 attending community hospital emergency departments in Pennsylvania and California.

This study findings shows that more than half of the sample were the victims of physical abuse, this will be observed by the children finally it may lead to the occurrence of psychological problems in the children.

About the family life, majority of the husbands got angry because the wives was refusing to have sexual intercourse and this is due to that man by nature does not like telling him not to have intercourse because it is considered an insult in his case and because the Islamic law prevented women from say no in the rights of the husbands. This agreed with the findings ${ }^{15}$. Sexual violence was probably underreported in the present study, less than $3 \%$ of the women were reported that husbands were physically forced them for sexual intercourse. Physical and psychological abuse combined was the most commonly occurring forms of women abuse.

For the threat of the husband to his wife was more than three quarters of respondents do not threaten people in front of others, because the nature of the man he loves to praise or criticize therefore avoid anything in front of others, even though no one is accountable.

\section{2. Recommendation}

One of the neglected health problems in the Port-Said City is women abuse. In this study, the researchers found out high prevalence of abuses among women by their own husbands. The Investigators also recognized the factors affecting abuses and types of abuses among married women. So the researchers are giving some recommendations to prevent abuses among married women and women in general.

* Arrange Women Empowerment Classes for women on self protection, self motivation, and self esteem measures

* Organize Self Assertive Training Programs for women to resist all forms of abuses.

* Conduct exploratory studies to determine the causes and risk factors of abuses among women.

* To prevent women abuse based on the risk factors determined from such study.

* Mass Education in the field of sexual responsibility of the women, rights in regard to support and protection from abusive husband

* Promotion and revision of supportive laws for abused women.

* Arrange counseling sessions for the victims and their families.

\section{Conclusion}

Woman is the most important person in the family. She is performing different task at a time like daughter, wife, mother, grand mother etc. Do you think that is it easy? She is suffered a lot for her family and for their children, but finally she is getting abuses and scolding from her husband or from others. That she can't tolerate. From the morning to late night she is working for the family, but no body is recognizing or appreciating her efforts and hard work. So she may be upset or under frustrations. Through this study the researchers were try to analyze the factors affecting abuses, to assess the socio-demographic data of the subjects and to identify the types of abuses experienced by the married women from their husbands. The result of the study shows that the women were exposed to one or other forms of abuses every day. More than half $(54 \%)$ of the samples were the victims of personal insult, $39 \%$ of them were getting beating with objects, $33 \%$ have financial problems. About $14 \%$ of the samples were fear from husband's doubt, $17 \%$ of their husband's making problems on sex. 
Around $14 \%$ of their husband's were having aggressive behavior. $17 \%$ of them were fear from threats of their husband. More than (54\%) of the witness of violence was their own children, $16.6 \%$ of the witnesses were their parents. Main recommendations of the study were to arrange Women Empowerment Classes for women on self protection, self motivation, and self esteem measures, Promotion and revision of supportive laws for abused women and arrange counseling sessions for the victims and their families. Finally help the Women to become Self Assertive to overcome the challenges of life.

\section{Acknowledgement}

The investigators are grateful to Almighty God for His guidance, strength, wisdom and support throughout this endeavour. The investigators extend their thanks to all administrators of Primary Health Centers and School of Nursing, Port -Said City, Egypt. The Investigators are expressing their gratitude to all the participants of the study.

\section{References}

[1]. Gil-Gonzales D, Vives-Cases C, Ruiz MT, Carrasco-Portino M, and Alvarez-Dardet C: Childhood experiences of violence in perpetrators as a risk factor of intimate partner violence: a systematic review.J Public Health 2007.advance access: 1-9.

[2]. Piquero AR, Brame R, Fagan J, Moffitt TE: Assessing the offending activity of criminal domestic violence suspects: offense specialization, escalation, and de-escalation evidence from the Spouse Assault Replication Program. Public Health Rep 2006, 121(4):409-418.

[3]. Krantz G, Garcia-Moreno C: Violence against women's Epidemiology Community Health 2005, 59(10):818-821

[4]. Krug EG, Mercy JA, Dahlberg LL, Zwi AB: The world report on violence and health. Lancet 2002, 360(9339):1083-1088.

[5]. Kabeer N, Anh TTV, Loi VM: Preparing for the future: forward-looking strategies to promote gender equity in Vietnam. Hanoi: World Bank Group; 2005.

[6]. Nicolaidis, Curry M, McFarland B, Gerrity M: Violence, mental health, and physical symptoms in an academic internal medicine practice. J Gen Intern Med 2004, 19:819-827.

[7]. Xu X, Zhu F, O'Campo P, Koenig MA, Mock V, Campbell J: Prevalence of and risk factors for intimate partner violence in China. Am J Public Health 2005, 95(1):78-85.

[8]. Dunkle KL, Jewkes RK, Brown HC, Yoshihama M, Gray GE, McIntyre JA, Harlow SD: Prevalence and patterns of gender-based violence and revictimization among women attending antenatal clinics in Soweto, South Africa. American Journal of Epidemiology 2004, 160(3):230-239.

[9]. Valladares E, Pena R, Person LA, Hog berg U: Violence against pregnant women: prevalence and characteristics. A populationbased study in Nicaragua.Bjog 2005, 112(9):1243-1248.

[10]. Carvalho T, Ozkanli O, Lourdes Machado M: Inequalities in Higher Education and Gender Inequalities in senior management: A comparative study from Portugal and Turkey. 2nd International RESUP Conference. LAUSANNE, 18-20 June 2009

[11]. Garcia-Moreno C, Jansen HA, Ellsberg M, Heise L, Watts CH: Prevalence of intimate partner violence: findings from the WHO multi-country study on women's health and domestic violence. Lancet 2006, 368(9543):1260-1269.

[12]. WHO Multi country study on women's health and life experiences questionnaire (version 9) Geneva: World Health Organization; 2000 .

[13]. Putting women first. Ethical and safety recommendations for research on domestic violence against women Geneva: World Health Organization; 2001.

[14]. Hegarty K, Hindmarsh ED, Gilles MT: Domestic violence in Australia: definition, prevalence and nature of presentation in clinical practice. Med J Aust 2000, 173(7):363-367.

[15]. Swahnberg K, Wijma B, Schei B, Hilden M, Irminger K, Wingren GB: Are Scio demographic and regional and sample factors associated with prevalence of abuse? Acts Obstetric Gynecology Scand 2004, 83(3):276-288.

[16]. Malcoe LH, Duran BM, Montgomery JM: Socioeconomic disparities in intimate partner violence against Native American women: a cross-sectional study. BMC Med 2004, 2:20.

[17]. Koenig MA, Ahmed S, Hussein MB, Khorshed Alam Mozumder AB: Women's status and domestic violence in rural Bangladesh: individual- and community-level effects. Demography 2003, 40(2):269-288.

[18]. Kaye D, Mirembe F, Bantebya G: Risk factor, nature and severity of domestic violence among women attending antenatal clinic in Mulago hospital, Kampala, Uganda. Central Journal of Medicine 2002, 48(5-6):64-8

[19]. Watts C, Zimmerman C: Violence against women: global scope and magnitude. Lancet 2002, 359(9313):1232-1237.

[20]. Tjaden PG, Thoennes N: Extent, Nature, and Consequences of Intimate Partner Violence. Washington, DC: U.S. Dept. of Justice, Office of Justice Programs, National Institute of Justice; 2000

[21]. Thompson RS, Bonomi A, Anderson M, Reid R, Dimer J, Carrell D, Rivara F: Intimate partner violence. Prevalence, types and chronicity in adult women. Am J Prev Med 2006, 30(6):447-457.

[22]. Krantz G, Van Phuong T, Larsson V, Thi Bich Thuan N, Rings berg KC: Intimate partner violence: forms, consequences and preparedness to act as perceived by healthcare staff and district and community leaders in a rural district in northern Vietnam. Public Health 2005, 119(11):1048-1055. 